\title{
Kalıcı kalp pili (icd) implante edilen diyabetik hastanın pil yerinde erken dönemde gelişen nekrozun rekonstriksiyonu
}

\author{
Reconstruction of necrotic tissue in the early period of permanent pacemaker \\ wound area in patient with diabetes mellitus
}

Hakkı Kaya*, Hasan Yücel, Orhan Doğdu, Ali Zorlu

Kardiyoloji Kliniği (Dr. H. Kaya), Sivas Numune Hastanesi, TR-58030 Sivas, Kardiyoloji Anabilim Dalı (Yrd. Doç. Dr. H. Yücel, Yrd. Doç. Dr. A. Zorlu), Cumhuriyet Üniversitesi Tıp Fakültesi, TR-58140 Sivas, Kardiyoloji Anabilim Dalı (Yrd. Doç. Dr. O. Doğdu) Fırat Üniversitesi Tıp Fakültesi, TR-23200 Elazı ̆

Geliş tarihi/Received: 09 Nisan 2014; Kabul tarihi/Accepted: 21 Nisan 2014

\author{
*İletişim adresi: \\ Dr. Hakkı Kaya, Kardiyoloji Kliniği, Numune Hastenesi, TR-58030 Sivas. E-posta: \\ drhakkikaya84@gmail.com
}

Sayın Editör,

Kalp pilleri, kalbin ritmini oluşturan ve düzenleyen elektronik cihazlardır. Jeneratör genellikle göğüs derisinin altında bir cep oluşturularak implante edilir. İmplantasyona bağlı cep bölgesinde nekrotik doku oluşumu, literatürde bildirilmemiştir. Diyabetik hastalarda kalıcı kalp pili yeri nekrotik doku oluşumunun olası nedeni ve farklı bir tedavi yaklaşımı olgumuzda açıklanmıştır. Altmış beş yaşında, Diyabetes mellitus ve dilate kardiyomiyopatisi olan hastaya EPS'de Sustained VT indüklenmesi üzerine ICD implantasyonu planland. Tek odacıklı (VR-ICD) ICD başarılı bir şekilde implante edildi. İşlemden yaklaşık 24 saat sonra yara sütür hattının altında yaklaş1k $2 \times 2 \mathrm{~cm}$ boyutunda nekrotik alan tespit edildi. Hasta plastik ve rekonstriktif cerrahi ile birlikte değerlendirildi. Yapılan değerlendirme sonrası bu bölgede açılan cebin küçük, gergin olması ve hastada diyabetin olması sebepleriyle dolaşım bozulduğu belirlendi. Yapılan tetkikler sonrası yara bölgesinde enfeksiyon tespit edilmedi. Hastaya profilaktik antibiyotik tedavisi verildi. Nekrotik alanın debridmanı sonrası rekonstriksiyon kararı verildi. Yapılan işlemde öncelikle nekrotik doku debride edildi (Resim 1). Debridman sonrası komşu bölgeden flep kaydırılarak bu bölge kapatıldı. Hasta bu işlem sonrası yaklaşı on gün boyunca takip edildi. Bu süre sonunda yara yerinin iyileştiği görüldü (Resim 2). Birinci ve altıncı aylarda yapılan kontrollerde pace bölgesinde nekroz ve enfeksiyon bulgusuna rastlanmadı. Implante edilebilir defibrilatör (ICD), kalp yetersizliği hastalarında aritmi ile ilişkili mortalitenin azaltılmasında oldukça etkilidir ve ani kardiyak ölümün önlenmesinde köşe taşıdır. Geniş çaplı randomize çalışmalarda bu etkisi gösterilmiştir [1-6]. Koroner arter hastalığ 1 ve kalp yetersizliği olan hastalarda, diabetes mellitus (DM) un eşlik etmesi ciddi sağlik problemlerinide beraberinde getirir [7]. DM yara iyileşmesini en sık bozan metabolik hastalıktır [8]. Diyabetik hastalardaki yaralarda destrüktif prosese neden olan patolojik olaylar; nöropatik dejenerasyon, vaskülopati (mikroanjiopati ve makroanjiopati), bozuk kollajen üretimine bağlı kötü yara iyileşmesi gibi farklı mekanizmaların kombinasyonundan meydana gelmektedir [9]. Diyabetik hastalarda kalıcı pil için cep açılırken vaskülopatinin yara iyileşmesi üzerindeki olumsuz etkileri göz önünde bulundurulmalıdır. 


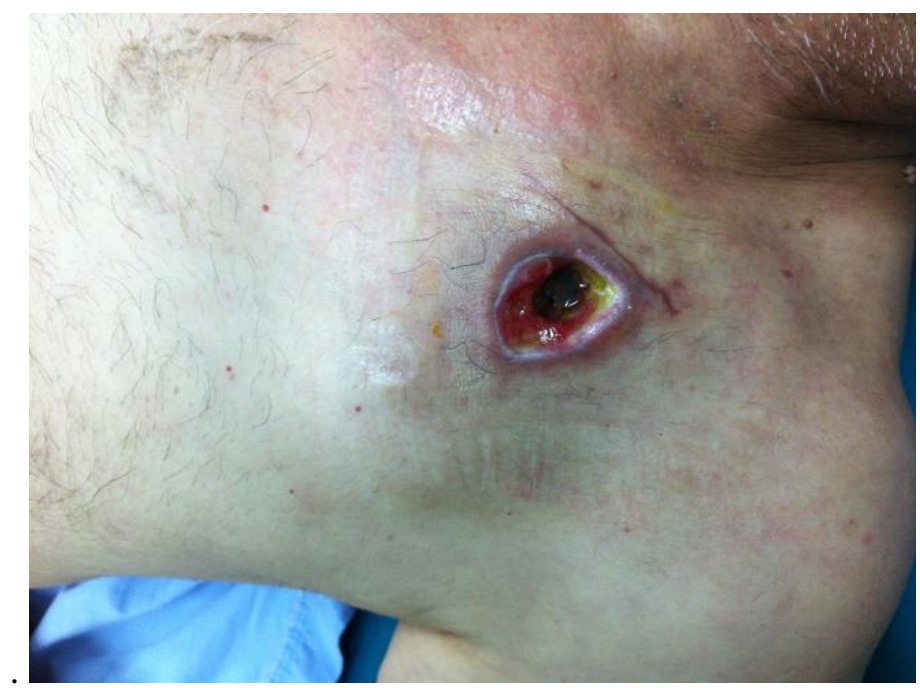

Resim 1. Erken dönemde kalıcı pace bölgesinde gelişen nekrotik dokunun debridmanı sonrası görünümü

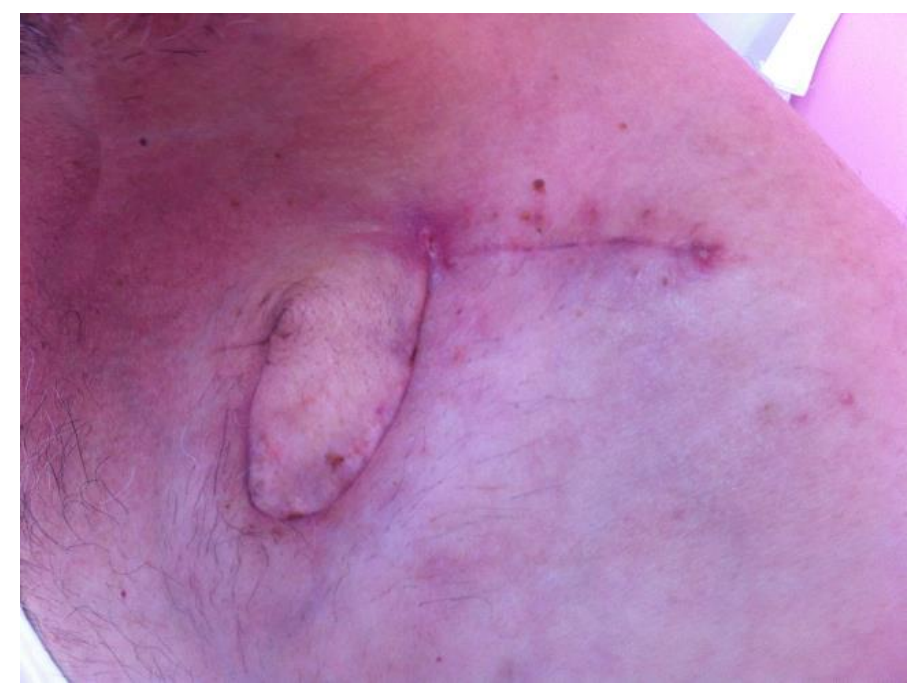

Resim 2. Rekonstriksiyonun onuncu gününde pace bölgesinin görünümü

Sonuç olarak; diyabetik hastalarda kalıcı pace implantasyonunda dolaşım bozukluğu ihtimaline karşı küçük ve gergin cep açılmaması uygun olur. 


\section{Kaynaklar}

1. Moss AJ, Hall WJ, Cannom DS. Improved survival with an implanted defibrillator in patients with coronary disease at high risk for ventricular arrhythmia. N Engl J Med 1996; 335: 1933-40.

2. The AVID Investigators. A comparison of antiarrhythmic drugtherapy with implantable defibrillators in patients resuscitated from near-fatal ventricular arrhythmias. N Engl J Med 1997; 337: 1576-83.

3. Buxton AE, Lee KL, Fisher JD. A randomized study of the prevention of sudden death in patients with coronary artery disease. N Engl J Med 1999; 341: 1882-90.

4. Moss AJ, Zareba W, Hall WJ. Prophylactic implantation of a defibrillator in patients with myocardial infarction and reduced ejection fraction. $\mathrm{N}$ Engl $\mathrm{J}$ Med 2002; 346: 877-83.

5. Bardy GH, Lee KL, Mark DB. Amiodarone or an implantable cardioverterdefibrillator for congestive heart failure. N Engl J Med 2005; 352: 225-37.

6. Bristow MR, Saxon LA, Boehmer J. Cardiacresynchronization therapy with or without an implantable defibrillator in advanced chronic heart failure. $\mathrm{N}$ Engl $\mathrm{J}$ Med 2004; 350: 2140-50.

7. Mandavia $\mathrm{CH}$, Aroor AR, DemarcoVG\&Sowers JR. Molecular andmetabolic mechanisms of cardiac dysfunction in diabetes. Life Sciences 2013; 92: 601-08.

8. Vasiliadis I, Kolovou G, Kolovou V. Gene polymorphisms and thyroid function in patients with heart failure. Endocrine 2014; 45: 46-54.

9. Tung P,\&Albert CM. Causes and prevention of sudden cardiac death in the elderly. Nature Reviews Cardiology 2013; 10: 135-42.

10. Chugh SS., Jui J, Gunson K. Current burden of sudden cardiac death: Multiple source surveillance versus retrospective death certificate-based review in a large U.S. community. Journal of the American College of Cardiology 2004; 44: 126875. 